\title{
Adapt or die: the views of Unisa student teachers on teaching practice at schools
}

Elize C Du Plessis

College of Human Sciences,

University of South Africa

P O Box 392, UNISA, 0003, Pretoria,

South Africa,

duplesec@unisa.ac.za
Petro Marais

maraip@unisa.ac.za

Alena Van Schalkwyk

vschaa1@unisa.ac.za

Fransa Weeks

weeksf@unisa.ac.za

\section{Acknowledgement}

We wish to thank Prof S. Schulze for her mentorship on this research project and acknowledge the contribution of Prof I. Sonnekus.

\section{Abstract}

This study focuses on the views of Unisa distance education (DE) students enrolled for the Postgraduate Certificate in Education (PGCE) who had completed their teaching practice. The research questions were: What are student teachers' experiences of the way in which Unisa prepared them for teaching practice, the school context in which they practised teaching, the mentoring they received or did not receive and the way they were assessed? Socio-constructivist learning and situated learning theory were used as the theoretical framework. A maximum variation sampling technique was used to select 16 participants who had completed 10 weeks of teaching practice to participate in the study. Data were collected by means of semi-structured interviews. The findings indicate that, in preparing students for teaching practice, all role players need greater clarity on what is expected of students with regard to learning outcomes, assessment criteria and lesson plans. Students need to be placed at schools that will provide constructive learning environments, mentoring teachers should receive training and there should be greater clarity on the who, what and how of the assessment of students during teaching practice. 


\section{E. C. du Plessis, P. Marais, A. van Schalkwyk and F. Weeks}

Keywords: assessment, distance education, mentorship, school context, situated learning, socio-constructivism, student teachers, teaching practice, Unisa preparation

\section{Introduction}

Most teachers remember the first time they stood in front of a class - no longer a learner looking up to the teacher but now a student teacher trying to live up to a perfect ideal or passionately trying to "perform" well. A student teacher can thus be defined as "a college or university student who is teaching under the supervision of a certified teacher in order to qualify for a degree in education" (Farlex 2008). Thus teaching practice can be described as the time in student teachers' training when they are exposed to school life under the guidance of a supervisor/mentor teacher.

Internationally, teaching practice is an issue that has been researched for some time (Robinson 2001). Although schools are willing to accommodate students, poor management, non-existent timetables, lack of staff and nonmentoring all impact negatively on the practice, leaving some students demotivated and disillusioned (Cilliế 2008, 8; Rademeyer 2008b, 20; Timm 2008, 4). Thus, the restructuring of teaching practice at schools is essential.

One of the biggest problems for distance education (DE), is overcoming transactional distance. There is a transactional gap between students teachers and the institution, between student teachers and lecturers/tutors, between students teachers and courseware and between student teachers themselves. It is the cognitive space between learning peers, teachers and content in a distance education setting (Moore 1993). The University of South Africa (Unisa) is faced with unique challenges - including student teaching practice - in the training of teachers. Lecturers at Unisa were urged by the Higher Education Quality Committee (HEQC 2008) to improve the student teachers' teaching practice experience by addressing the following components: selection of schools, placement of student teachers, training of mentors and mentoring during the teaching practice period and assessment of student teachers' competence and feedback to the university by the mentor/supervising teachers.

This research, which focused on the Postgraduate Certificate in Education (PGCE), is an evaluative study by the authors who are involved in this programme. To enroll for the PGCE, students need an approved degree or equivalent qualification. The purpose of the PGCE is to provide students with the skills, knowledge and attitudes teachers need. 


\section{Background to the research: the HEQC and modules of teaching practice}

According to the HEQC, the current system of teaching practice should ensure that the relationship between an institution and schools involved in teaching practice is clarified. This implies, that effective systems of communication are in place, and that institutions play an active role in the placement of students. Furthermore, mentors need to support and assess student teachers.

There are various programmes of student teaching practice at different institutions. For example, at the University of Pretoria, PGCE students do 10 weeks of practical teaching (University of Pretoria 2008), while the North-West University prescribes at least two weeks of practical teaching (North-West University 2008). The University of Johannesburg requires a practical teaching period of between eight and 10 weeks (University of Johannesburg 2007). At the Nelson Mandela Metropolitan University (Nelson Mandela Metropolitan University 2008) and the University of the Free State (University of the Free State 2008) practical teaching periods are prescribed by Senate at will.

Although Unisa consulted various teaching practice programmes and the Norms and Standards Document for Educators (Department of Education 2000) only the Government Gazette (Department of Education 2007, 13-15) prescribed a practical teaching period which would be the equivalent of a year (120 credits) for the 480 credit BEd qualification. After deliberation, lecturers decided on the following: all phases of the PGCE (Foundation, Intermediate and Senior, and Senior and Further Education and Training) would have to meet the same requirements. Students would identify schools for their 10 weeks of practical teaching. Their teaching would be evaluated by mentors or senior teachers. Students would complete workbooks, principals write reports, and these would be submitted to Unisa lecturers for assessment (Unisa 2006, 2007, 2008).

This model of student teaching practice was subsequently implemented. However, no formal research has been done to determine students' views on various aspects of the model, in particular the role of the school context, the mentoring the students receive and how they are assessed. This research project, which was intended to fill this gap, was framed by the learning theories explained in the next section

The research questions were: What are student teachers' views of the way in which Unisa prepared them for teaching practice, the school context in which they practised teaching, the mentoring they received or did not receive and the way they were assessed? 


\section{Conceptual framework}

Two learning theories supported this study: situated learning and socioconstructivist learning. In teaching practice, the roles of "masters" (e.g. mentors) and "apprentices" (e.g. student teachers) in a practical learning situation are the point of departure for all learning activities. Lave and Wenger's (1991) theory of situated learning is based on two principles, namely that learning takes place as a function of the context, culture and activity in which it occurs, and that learning is a process that occurs in a participatory social context. The participants are the "master teachers" and the "apprentices/learners" (student teachers). Learners acquire the knowledge and skills they need to perform in the classroom by engaging in the school situation. Thus, they apply the abstract knowledge they acquired through their studies to real-life situations.

Two concepts are relevant for situated learning theory: "community of practice" and "legitimate peripheral participation". Learners develop and identify with the practices appropriate for a specific community. Wenger identifies three elements that define a community of practice, namely mutual engagement of participants in action, negotiation of a joint enterprise and development of a shared repertoire. Learners are legitimate peripheral participants in the practices of the teaching community during their practical teaching under the guidance of experienced teachers as mentors. Lave and Wenger $(1991,32 ; 50 ; 70)$ view learning as a social process where identity, membership (a need to belong in order to learn) and inter-personal relationships are significant (Beck and Kosnik 2002, 82).

Socio-constructivists claim that the personal construction of knowledge always occurs in social contexts, since learning activities are socially and contextually bound. The socio-constructivist perspective on learning sees learning as an active process of constructing meaning and transforming understandings during interaction with the environment. Learners should play an active role in constructing knowledge as learning is collaborative and learners learn from mentors and one another. There should be a continuous reciprocal interaction to ensure that this learning process is productive and successful. This approach is in favour of student-centred teaching and learning and places the learners' own efforts to understand at the centre of educational events (Woolfolk 2007, 481).

Socio-constructivists believe that learners should deal with complex real-life situations. They need ample opportunities to engage in meaningful, problembased activities. Students therefore need to plan and present lessons, and manage disruptive behaviour and administrative tasks during teaching practice. Their ideas should also be elicited in respect of the above (Collins, Brown and Holum 1991, 38-39). When planning and presenting lessons, students are asked to apply 
knowledge in diverse and authentic contexts, to explain ideas, interpret text and construct arguments based on evidence. They continually need to articulate their knowledge and understanding and consult various resources. Students should also work collaboratively and support one another in task-oriented dialogue. Supporters of the socio-constructivist approach emphasise that mentors make their own thinking processes explicit to students and encourage them to do the same through dialogue, writing and drawings. Mentors employ a variety of assessment strategies although self-assessment is also encouraged. Collins, Brown and Holum (1991, 38-39) point out that students need to reflect on their progress and compare their teaching with the performance of mentors and with their own earlier performances.

The following paragraphs contain a brief review of relevant literature. The focus is on the most important issues in teaching practice, namely student preparation, the school context, mentoring and assessment.

\section{Institutional student preparation}

In their research, Marais and Meier $(2004,230)$ found that students were confused and lacked insight into the relationship between the theory they were taught by institutions and teaching practice. They were therefore unable to relate what they had learnt from their tutorial matter to the teaching practice they encountered at schools. Some students were disillusioned by the heavy workloads they were expected to carry after hours in the form of marking, checking, assessing learners' work and lesson preparation (Beck and Kosnik 2002, 94-95). The students believed they had not been well prepared for the reality of teaching practice at schools. Students experienced a need for learning content related to the nature of the child, teaching, school routine, individuality, group assessment, teaching methods, motivation, positive reinforcement, ways of creating a stimulating classroom, classroom layout and staff meetings. They felt that they had been left in the dark about the reality that awaited them when they reported for teaching practice at schools and this confusion extended to assessment practices used in teaching practice (Dreyer 1998, 109). Various authors (e.g. Dreyer 1998, 109; Marais and Meier 2004, 230; Ngidi and Sibaya $2003,21)$ therefore emphasise that there is a need for universities to inform student teachers about what is expected of them during their teaching practice in order to lessen their anxiety about teaching practise.

In support of the above, $\operatorname{Ngcobo}(1989,19)$ maintains that there is an obvious lack of effective liaison between universities and schools that gives rise to the theory/practice dichotomy, which was regarded by students as the most significant problem confronting them during their teaching practice. According 
to $\operatorname{Ngcobo}(1989,19)$, teacher preparation modules teach students about teaching and not about "teacher education" as a scientific area of study. Insight into teacher education can change teachers' perceptions of their role in relation to students. At the same time he recommends that a module on Teacher Education should be introduced into teacher preparation programmes as part of in-service training.

\section{The school context}

If professional development initiatives do not have the infrastructure to enable them to work, student teaching practice will become an obligation and a burden rather than a learning experience. In a climate of demotivation it is difficult to promote any professional development programmes.

Robinson $(2001,113)$ argues for a restructuring of daily experiences at schools to make these more meaningful for students. Schools could add more value to teaching practice if they were directly asked to do so and given guidance on what was expected of them during students' period of teaching practice. A lack of guidance leads to lost opportunities (Quick et al 2005, 66). Such guidance could include the consideration of gender, age and grade placement when students are placed for teaching practice (Ngidi and Sibaya 2003, 20).

Schools complain that higher education institutions do not prepare them for partnership arrangements between schools and the training institutions in respect of the student teachers doing their teaching practice at schools, which results in student teachers and staff at schools having numerous negative experiences. Marais and Meier $(2004,230)$ established that negative experiences included exposure to poor discipline in the classrooms and the enlistment of students as cover teachers, thus precluding the presentation of lessons as planned. It was also clear that demonstration lessons by experienced teachers could not be a once-off event but needed to be ongoing and cover a variety of lessons (Boz and Boz 2006, 353).

\section{Mentoring student teachers}

Clark and Marker (in Kader 2003, 10) explain the importance of mentoring as follows: "If, as the research indicates, practice teaching is the 'single most powerful intervention in teachers' professional preparation; then supervision [mentoring] is the single most powerful process in such intervention." Lecturers and teachers therefore have to work as a team and coordinate their efforts to enhance mentorship in schools. Mentor teachers should concentrate on building strong relationships of trust and goodwill with students and institutions (Mohono-Mahlatsie and Van Tonder 2006, 394-395). 
The qualifications and teaching experience of mentor teachers significantly influence the mentor student teacher's experience (Nyaumwe 2001, 230). Marais and Meier $(2004,230)$ corroborate this by saying that there is a need for mentor teachers to upgrade their qualifications. They suggested written guidelines on training opportunities such as workshops for mentor teachers.

Student teachers would like to see a professional attitude in mentor teachers. Marais and Meier's $(2004,220,226)$ findings indicated that the supportive aspect of the mentoring relationship was important to student teachers (Pinnock 2007, 22). Student teachers appreciated the fact that teaching staff at schools respected and accepted them and made them feel welcome. At some schools, student teachers received significant help and continuous guidance from principals and other teachers. The majority of student teachers experienced mentor teachers as friendly, understanding and always willing to help. They said mentor teachers offered valuable advice, creative ideas and tips, and shared their skills and accomplishments.

Student teachers reported that they had gained invaluable experience for which books could never be a substitute. Through mentoring student teachers learn how to be well organised and well prepared to carry out their daily activities. Quality feedback from mentor teachers enhanced the self-image of the student teachers to such an extent that student teachers said that teaching practice had motivated them to teach. Caires and Almeida (2005, 117-118) confirmed the above-mentioned findings, namely that a positive teaching practice experience could be "a real personal revolution". This was particularly attributed to the assistance of a dedicated mentor teacher - described by student teachers as a marvellous support system.

Although the majority of student teachers generally rated the mentor teachers positively as role models, there were some problems regarding mentoring (Marais and Meier 2004, 226). These included teachers who were unwilling to devote enough time or attention to student teachers, who requested student teachers to cover for them when they left the classroom, who lacked the competence to enhance the learning experiences of student teachers or who were guilty of unethical behaviour. Moreover, mentor teachers were often unaware of their expected roles and were therefore ineffective when supervising student teachers (Mavhunga 2004, 66).

Mavhunga $(2004,66)$ has recommended the following for effective mentoring: a strong partnership with more meetings between the training institutions and the schools so that both partners are able to operate on the same footing, the sharing of goals and approaches regarding the supervision/mentoring of student 
teachers, more formal and structured arrangements, lecturers visiting schools on a more regular basis and supervising more lessons or inviting school staff to the university, and supervision of lessons by subject area specialists.

Various other authors have also argued for a stronger relationship between schools and institutions to enhance mentoring. For example, Quick and Sieborger $(2005,3)$ indicated a need for better communication between student teachers, supervisors, liaison people and university lecturers in view of the lack of training of mentor teachers at schools. Marais and Meier $(2004,230)$ and Maphosa, Shumba and Shumba $(2007,305)$ emphasised that lecturers and teachers have to work closely together in order to ensure coordinated efforts to enhance mentorship in schools.

\section{The role of assessment}

Closer cooperation between institutions and schools not only improves mentoring but should ultimately lead to a more effective assessment process. According to Mohono-Mahlatsi and Van Tonder (2006), a mentor's assessment indicates what a student teacher needs to know in order to grow professionally. Research by these two researchers has shown that student teachers experience the following problems regarding assessment:

- Classroom observations were not executed often and repeatedly, yet these observations were used for assessment outcomes.

- There were not enough guidelines and memoranda for assessing their presentations.

- Assessment criteria appeared to be inconsistent applied.

- Assessment confused the student teachers as some of them received higher marks at times for conducting the same activities as previously without remarks or explanations from the mentor teacher.

- Assessment was sometimes followed by late feedback from mentor teachers.

- Some assignments were left without any comments or if comments were supplied these were not detailed.

According to mentor teachers, the above-mentioned occurred because of a lack of information on administrative issues and academic changes in time and work schedules at schools. Ngcobo $(1989,20)$ also stated that student teachers felt that they were viewed negatively most of the time, as mentor teachers overemphasised assessment as opposed to the other roles a mentor teacher plays, such as guiding, advising, counselling and supporting the student teacher in general. 
The problem of a lack of or delayed assessment of practical assignments was also identified by Mohono-Mahlatsi and Van Tonder (2006). This affected the performance of student teachers. Marked assignments were meant to help student teachers to improve on their performance. However, student teachers sometimes received feedback on the first assignment only after the second or even third assignment had been submitted.

Furthermore, Ngcobo $(1989,20)$ established that student teachers felt threatened by the lecturers who had to evaluate their competence as teachers. They tended to believe that the issue here was obtaining a high degree of competence. The real point of such evaluation should be to secure valid and reliable data on the quality or level of the student teachers' efforts in fulfilling their responsibilities and to provide a basis for improvement.

Against the background of the conceptual framework and the literature review, the following methodology was deemed suitable for investigating the way in which a group of Unisa students experienced teaching practice. In particular the focus was on student teachers' views on their preparation for teaching practice, the role of the school context where they practised teaching, the mentoring they received and how they were assessed.

The research employed a qualitative research approach using a phenomenological research design to obtain an understanding of the views of student teachers. Purposeful sampling was used to select 16 information-rich participants. All the participants were from South Africa and were enrolled for the same Postgraduate Certificate in Education (Senior Phase and Further Education and Training). Students enrolled for this certificate have to complete 10 weeks of teaching practice in schools. Maximum variation sampling was used (McMillan and Schumacher 2006, 320). Both genders and a wide range of ages (23 to 61 years of age) were involved. Moreover, student teachers completed their practice at varied locations, ranging from those that were rich in human and other resources to those deficient in them. Different cultural groups were also involved. The sample was identified from a class list of student teachers who were then contacted by telephone and asked to participate. The fact that the interviews were conducted in person limited the research somewhat in the sense that only those student teachers who lived in the Gauteng area were included in the research project.

Semi-structured interviews were conducted with the participants (McMillan and Schumacher 2006,354). The interviews were conducted in a conversational manner but using an interview guide. Each interview began with an explanation of the purpose of the interview, a promise of confidentiality and a reassurance 


\section{E. C. du Plessis, P. Marais, A. van Schalkwyk and F. Weeks}

that there was no right or wrong answer. The same questions were posed to all participants in the same sequence. Participants were asked how they felt about the various issues mentioned above. In the case of each issue they were asked what worked well, what did not work well, and what they could recommend. Interviews lasted approximately 60 minutes and were tape recorded. All necessary ethical measures were adhered to, including obtaining informed consent from the Department of Education.

Different tactics were used to eliminate bias. These included a maximum variation of participants, mechanically recording interviews and transcribing these verbatim, using multiple researchers, and returning to interviewees when there was a lack of clarity about meanings. The findings are presented next.

\section{Findings and discussions}

\section{The role of Unisa's preparation}

The participants were in agreement that the Unisa lecturers provided them with clear study material and tutorial letters, well-prepared documents based on syllabi that were in line with the National Curriculum Statement and with the Integrated Quality Management System (IQMS). According to them, the well-structured tutorials on lesson preparation had clear guidelines and practical examples that made this task easier. Participants also remarked favourably on ideas included in the material for use in classroom settings (for example case studies). The clear layout lesson plans served as a broad-based framework for teaching practice. A participant stated that she "knew what is expected of me as a student", including "to read more". Another female participant believed that the Unisa material supplemented existing subject knowledge. Another participant stated that the theoretical foundation was a good preparation for most practical situations. He knew exactly what was expected of him in respect of practical teaching: "This translated the theory for the different modules into practice in the classroom very nicely for me."

On the other hand, some negative aspects were also pointed out. These included the fact that guidelines on lesson plans were not sufficient. A 23-year-old male felt that the academic introduction to practical teaching was poor - more information regarding learning outcomes and assessment criteria was needed. This participant remarked that he had found a discrepancy between the guidelines of the Department of Education and Unisa's guidelines on the content of a lesson plan. According to the Department of Education, an activity can be considered to be a lesson on its own, while Unisa requires theoretical content as well as activities for one lesson. He found this confusing. Another remark on lesson 
plans came from a 61-year-old female participant. She claimed that the time allocated to a lesson according to the Unisa guidelines in the workbook was 40 minutes while the school where she did her teaching practice only had periods of 30 minutes. She was thus unable to finish the lessons she presented.

The following recommendations were made by the participants: clearly stated learning outcomes and assessment standards, clear examples and specific guidelines indicating lecturers' expectations, lists of recommended books to use as additional material for school subjects, and more teacher involvement when students needed clarity on issues. According to a 25-year-old male, the material on how to improve lessons was not self-explanatory and he had had to ask other teachers for clarification of terminology used in the module to enable him to understand the material and the concepts.

From the above, it is clear that Unisa needs to concentrate on relevant preparation by means of more practical examples and experiences. This links to exposure to resources which should be embedded in module materials and presented to student teachers in a logical sequence. This reflects the principle of staggering as proposed by Wenger (Lave and Wenger 1991, 117,122-123). The resources give the student teachers access to the cognitive tools which they need to master the PGCE. Cognitive tools include the specialised set of terms that are required for effective learning, which create a common language for use by the student teachers and the Department of Education (DoE), giving them entry to the teaching profession. This is also in accordance with situated learning theory. If the Unisa preparation was limited in some ways, student teachers felt lost or overwhelmed. They then needed emotional support from Unisa or from the teachers who mentored them during their teaching practice at a school. This brings us to the school's role during teaching practice.

\section{The role of the school}

Participants were asked what worked well at the school where they did their teaching practice. At most schools the staff were very professional with a good team spirit. Student teachers were welcomed by school principals and received all the support they required. One participant at a rural, well-resourced school said that she had felt totally involved in the school - "just like part of the school". Another participant at a well-resourced, high school said: "Practical experience ... standing in front of a class ... gives you an understanding of the reality of teaching". In reference to a well-resourced private school, one participant referred to the excellent, well-established team of staff members who gave him support through the beginning stages, for example by supplying him with material for lessons. Most of the participants experienced the schools as being 
very supportive, felt part of the school and felt great about being involved in practical teaching.

Participation is a way of learning which allows the learning curriculum to unfold in opportunities for engagement in practice, in accordance with situated learning theory (Lave and Wenger 1991). The social context at the schools therefore encouraged collaborative learning by means of groups that included student teachers and staff members. Such social interaction addressed the student teachers' differing needs by taking into account their social and cultural backgrounds (Woolfolk 2007, 346). The social process at schools is significant in respect of identity, membership and inter-personal relations. Close relationships provide an opportunity to clarify expectations, and allow for empowering actions and whole school involvement, which are all very important. This gives prominence to the role of peers in the above social contexts. Because of the function of context, the positive aspects of the student teachers' relationship with teachers during teaching practice revolves around the teachers' professionalism and expertise in their mentoring role.

The different school contexts were also experienced as interesting. A participant who did teaching practice at a private well-resourced school testified that it worked well. He said: "I can fill a notepad because there were exciting things that happened ... or different things that happened ... different situations came up. What is fascinating about the whole teaching environment is that it is so dynamic. It changes all the time and you never know what is going to come up next."

The student teachers needed to participate actively in the school contexts for learning to take place. However, it is not always easy to operationalise "participation" (Hodkinson and Hodkinson 2003; Hodkinson and Hodkinson 2008). These authors point out that "practice" is merely an activity whereas "participation" is a meaningful activity. The importance of actively doing in the relevant context was pointed out by Jonassen and Rohrer-Murphy $(1999,61)$. In this regard, one participant said: "Practical experience by standing in front of a class gives you an understanding of the reality of teaching". Such a statement unconsciously supports activity theory, which postulates that conscious learning emerges from activity (performance) (Jonassen and Rohrer-Murphy 1999, 61). Thus, although some student teachers felt that they had been thrown in at the deep end, they recognised that it was a good and positive experience.

There were also some negative remarks about the school context. For example, a participant who practised teaching at a well-resourced school mentioned a lack of transparency in the way the school functioned. Another participant remarked: 
"I don't know if my second teaching practice was enough experience of the teaching environment". This may indicate that the student teacher practised teaching in a context that provided little opportunity for learning since she did not get the opportunity to be actively involved and thus learn.

Regarding the organisation of the PGCE, a 22-year-old female recommended a standardised system for the number of lessons in both the learning area didactics and the subject didactics. Some student teachers also recommended a longer period of teaching practice to improve experience and enhance learning.

\section{The role of mentoring}

The 31-year-old male commented favourably on his mentor, who had given him the opportunity to manage classes on his own while he gave high-quality guidance. With the mentor's superior knowledge and effective management of classes, he was a first-rate role model. A 24-year-old female said that she had had a good relationship with her mentor as they discussed lessons thoroughly twice a week. The mentor had explained what did not work well, told her how to improve her lessons and encouraged her. Being placed with a highly experienced teacher was seen as "a bonus" by one of the participants. From this teacher she learnt how to give individual attention to learners in spite of a heavy workload. Through participation she also learnt how to assess learners, in line with situated learning.

However, some participants reported unhelpful or depressing experiences. For example, a 23-year-old male indicated that mentor teachers should be more involved in students' teaching practice. Similarly, a 25 -year-old male reported that different mentor teachers had given different guidelines for the presentation of lessons and that this had caused confusion. Another 27-year-old male said that the mentor teacher had exploited him by making him present lessons for the whole day on her behalf.

Participants wanted mentors to protect them and keep an eye on them, especially in matters involving learners' parents. All the student teachers pleaded for more structured and standardised guidelines on what would be expected of mentors and students. It was suggested that Unisa could distribute handouts to teachers and schools explaining these expectations clearly. A 31-year-old male recommended a more formal "critique lesson" with more direct and transparent feedback from the mentor. It was suggested that the mentor should be prepared for the arrival of a student teacher. This participant also believed that mentors should indicate in good time when a student teacher was going to be expected to present a lesson as student teachers needed more time to prepare lessons properly. A 25 -year-old 


\section{E. C. du Plessis, P. Marais, A. van Schalkwyk and F. Weeks}

male stated that mentors needed to consider the fact that they were role models for student teachers. She also recommended that mentors treat student teachers as colleagues to enable them to maintain discipline.

According to the participants, the actual bricks and mortar of a school are not important to the student teacher. However, the student teachers' mentors during the period of teaching practice are of the utmost importance. Student teachers wanted more active support from them. This included support regarding subject knowledge, such as the clarification of unfamiliar concepts. Student teachers participate legitimately in teaching when they are treated as actual colleagues (Lave and Wenger 1991, 53-54; 122). This happens when they are allowed to participate "fully in a task, job or profession" (Brown and Duguid in Handley, Sturdy, Fincham and Clark 2006, 644). Such participation depends on the mentor, who is the dominant partner in the teacher-student-relationship - a fact which student teachers must accept. However, student teachers may sometimes be disappointed when they realise that teacher mentors are not always quite as masterful as they had expected them to be.

This may require a de-centred view of the relationship between the mentor and student teacher as proposed by Lave and Wenger (1991, 94). If conflict exists between the student teacher and a mentor, this needs to be resolved in accordance with the application of the situated learning theory. As indicated by participants, personality differences may also impact on the interpersonal relationships between student teachers and mentors. Thus, student teachers need to be placed with teachers who will suit their personalities. A further suggestion made by a 47-year-old female was that student teachers be assessed by the mentor according to the DoE's Integrated Quality Management Systems (IQMS). The next paragraph elaborates further on assessment.

\section{The role of assessment}

Participants made a number of positive remarks about assessment. One female indicated that she had received feedback from her mentor after each lesson. Another female said that her mentor had recast negative issues as positive criticism. A 35-year-old male indicated that he had not been assessed by Unisa staff, but had been formally assessed internally by a teacher. They did not seem to know what or how to assess. This resulted in big differences between the way Unisa staff and these teachers assessed their student teachers. Particular mention was made of a difference in assessment criteria for diverse learning areas such as didactics and subject didactics. 
Participants suggested that assessment practices could be improved by offering

- more guidance from Unisa on how to assess

- formal checklists (specific standardised assessment forms) to assess lessons

- feedback from Unisa in the form of formal post-assessment discussions to provide student teachers with a knowledge of how to improve lessons

- more continuous assessment

- a systematic introduction to teaching practice with special reference to the assessment component

- a more detailed written assessment from mentor teachers after lessons have been presented

- assessment from teachers other than mentor teachers

- assessment by Unisa lecturers

- some means by which student teachers can assess their own growth

Student teacher responsibility is emphasised by the constructivist theory of learning (Grabinger and Dunlap 1995, 5). To this end, teachers need to incorporate the needs and experiences of student teachers into learning activities so that student teachers can take ownership and responsibility for their learning. A 28-year-old female, who took on extra responsibilities, pointed out that there were no assessment criteria or rewards for this.

Finally, a student teacher should develop an identity as a teacher during teaching practice. According to Hodges $(1998,273)$, practice and identity are continually informed and reconstructed. This occurs when mentors are encouraging in their assessment of student teachers. This relates to Wenger's $(1998,149)$ proposal that "as newcomers participate, their identities develop according to how they experience themselves and the feedback and acceptance they receive from others". It seems that teaching practice has a significant and wide impact on student teachers' personal and professional development. A real "personal revolution" should take place if student teachers have the opportunity to discover themselves in the role of teachers, to interact with a new set of situations, to practice and play new professional roles or to acquire, develop and/or consolidate new skills and knowledge (Caires and Almeida 2005, 117-118).

Contrary to the above, dis-identification is possible if a student teacher is given negative feedback continuously (Hodges 1998, 272, 287). In one example a participant believed that her mentor had expected too much of her. A 35- yearold male participant also stated that students needed to be assessed by more than one person, including other teachers (see Harm 2009, 155). In short, the 
findings emphasise the importance of all the participants in assessment: Unisa, the school, the mentor and the individual student teacher.

\section{Conclusion}

As the HEQC (2008) required that the organisation of Unisa teaching practice needed to be improved, the aim of this study was to determine student teachers' experiences pertaining to some of the important issues in teaching practice. This study concentrated on how the PGCE prepared student teachers in secondary schools for teaching practice, the role of the school context, the mentoring they received if any and the way in which they were assessed.

As regards Unisa's preparation of student teachers, it was clear that the main issues that needed to be addressed related to greater clarity on what would be expected of student teachers (regarding learning outcomes, assessment criteria, guidelines on how to develop lesson plans - including practical examples, and lesson content). It was felt that Unisa would better prepare its students for teaching practice if workbooks and their terminology were in line with HEQC (2008) requirements.

From the findings, it was clear that the teaching practice schools should be selected for their ability to provide a rich environment for active involvement and thus learning. For student teachers to learn as much as possible, school contexts needed to be transparent so that they could construct knowledge meaningfully. Unisa needed to ensure that there was effective collaboration and socialisation between staff and student teachers during teaching practice. The findings indicated that selection criteria for student teacher placement should be based on more than just school resources.

It was clearly important that mentoring should be carefully thought through and discussed by the various stakeholders so that there was greater clarity on what is expected of mentors. There was a call for improved collaboration with schools. It was suggested that collaboration, discussion and mentor training should include Unisa lecturers, school principals and teachers. Mentors had an obligation to provide student teachers with emotional support and opportunities to develop their own identities as teachers, as well as to create challenging and complex environments in which to learn.

Finally, it was emphasised that assessment could be problematic. The way in which formative assessment modules and assignments should be staggered according to student teachers' needs required further investigation. After further discussion, decisions were needed on who should be involved in assessment 
during teaching practice (e.g. lecturers, teachers and the student teachers themselves), what needed to be assessed and how this should happen (the assessment criteria). Student teachers and Unisa lecturers needed to be provided with feedback after assessment. This would encourage student teachers to take responsibility for their own learning. Constructive feedback would also enhance their identity development as teachers. In particular, further research was required in respect of mentoring and assessment to provide the most suitable environment for student teaching practice. Ultimately all of the above would provide South Africa with superior teachers.

\section{References}

Beck, C. And C. Kosnik. 2002. Components of a good practicum placement: Student teacher perceptions. Teacher Education Quarterly. ProQuest Education Journals, 29(2):81-93.

Boz, N. and Y. Boz. 2006. Do prospective teachers get enough experience in school placements? Journal of Education for Teaching, 32(4):353-355.

Caires, S. and L. S. Almeida. 2005. Teaching practice in initial teacher education: Its impact on student teachers' professional skills and development. Journal of Education for Teaching, 31(2):117-118.

Cilliế, J. 2008. Luister of ons loop, sệ X-ers. Beeld Sake 24, 23.06.2008:8.

Collins, A., J. S. Brown and A. Holum. 1991. Cognitive apprenticeship: Making thinking visible. American Educator, 15(3):38-39.

Department of Education. 2000. Norms and standards for educators. Government Gazette Vol 415, No. 20844. 4 February. Pretoria: Government Printer.

Department of Education. 2007. Government Gazette Vol 502:13-15. 26 April. Pretoria: Government Printer.

Dreyer, J. 1998. The use of mentors (experienced teachers) as school-based experts to assist student and beginner teachers. South African Journal of Education, 18(2):109-112.

Farlex, 2008. Free Dictionary. [Online] Available at http://www.thefreedictionary. com/practice+teaching (accessed on 14 October 2008).

Grabinger, R.S. and J. C. Dunlap. 1995. Rich environments for active learning: A definition. Association for Learning Technology Journal, 3(2):5-34.

Handley, K., A. Sturdy, R. Fincham. and T. Clark. 2006. Within and beyond communities of practice: Making sense of learning through participation, identity and practice. Journal of Management Studies, 43(3):641-653.

Harm, H.T. 2009. Assessment for learning to teach: Appraisal of practice teaching lessons by mentors, supervisors, and student teachers. Journal of Teacher Education, 60(2):151-157. 
Higher Education Qualification Committee (HEQC). 2008. Audit report, 12 May. Council on Higher Education (CHE).

Hodges, D.C. 1998. Participation as dis-identification with/in a community of practice. Mind, Culture and Activity, 5(4):272-290.

Hodkinson, P. and H. Hodkinson. 2003. Individuals, communities of practice and the policy context: School teachers' learning in their workplace. Studies in Continuing Education, 25(1):3-21.

Hodkinson, P. and H. Hodkinson. 2008. Rethinking communities of practice: A case study of schoolteachers' workplace learning. [Online] Available at http://www.tlrp.org/project\%20sites/IILW/pr5\%20H-Tampere, Paper\%20 141.htm (accessed on 13 May 2008).

Jonassen, D.H. and L. Rohrer-Murphy. 1999. Activity theory as a framework for designing constructivist learning environments. Educational Technology, Research and Development, 47(1):61-80.

Kader, S. 2003. The role of the co-operating teacher in supervising student teachers during the teaching practice. Unpublished Masters thesis: University of Port Elizabeth.

Landman, W. 2008. Beter skole is ANC se morele plig. Beeld Sake24, 28.08.2008:12.

Lave, J. and E. Wenger. 1991. Situated learning: legitimate peripheral participation. Cambridge University Press: Cambridge.

Maphosa, C., A. Shumba and J. Shumba. 2007. Mentorship for students on teaching practice in Zimbabwe: Are student teachers getting a raw deal? South African Journal of Higher Education, 2:296-307.

Marais, P. and C. Meier. 2004. Hear our voices: Student teachers' experiences during practical teaching. Africa Education Review, 1(2):220-233.

Mavhunga, P. J. 2004. A study of the role of teacher-mentors in the supervision of secondary school student teachers on teaching practice attachment. Zimbabwe Journal of Educational Research, 16(1):52-69.

McMillan, J.H. and S. Schumacher. 2006. Research in education: Evidence based inquiry. (6th edition.) Boston: Pearson.

Mohono-Mahlatsi, L. and F. van Tonder. 2006. The effectiveness of mentoring in the distance teacher education programme at the Lesotho College of Education: Student teachers' and tutors' perceptions. South African Journal of Education, 26(3):383-396.

Moore, M.G. 1993. Theory of transactional distance. In Theoretical principles of distance education, ed. D. Keegan. New York: Routledge.

Naudẻ, C. 2007. Slegte nuus oor onderwys, goeie nuus oor wenkultuur. Beeld Sake24 13.11.2007. Pretoria. 
Ngcobo, B.W. 1989. The problem of conflicting expectations between schools and teacher education institutions during practice teaching supervision. Educamus, 35(5):19-25.

Ngidi, D.P. and P.T. Sibaya. 2003. Student teacher anxieties related to practice teaching. South African Journal of Education, 23(1):18-22.

Nyaumwe, L. 2001. A survey of Bindura University of Science Education student teachers' perceptions of the mentoring model. Zimbabwe Journal of Educational Research, 13(3):230-244.

Pinnock, A. 2007. Successful mentoring: The students' view. Teaching Business and Economics, 11 (3):22-26.

Quick, G. and R. Sieborger. 2005. What matters in practice teaching? The perceptions of schools and students. South African Journal of Education, 25(1):1-4.

Rademeyer, A. 2008a. Net 46\% gr 1's vorder tot gr. 12. Beeld, 13.08.2008: Pretoria.

Rademeyer, A. 2008b. Opvoeders is swak toegerus. Beeld, 28.08.2008:20. Pretoria.

Robinson, M. 2001. Teachers as mentors: A critical view of teacher development in S.A. schools. Perspectives in Education, 19(2):99-115.

Timm, S. 2008, Steer clear of incompetent mentors, small firms warned. Business Report 26.06.2008: 4. Johannesburg.

UNISA. 2006. Tutorial letter: Teaching Practice. PRS2049/102/2006. Pretoria: UNISA.

UNISA. 2007. Tutorial letter: Teaching Practice. PTEAC1X/101/2007, PTEAC2Y/101/2007. Pretoria: UNISA.

UNISA. 2008. Tutorial letter: Teaching Practice. PST402T/107/2008. Pretoria: UNISA.

Van Niekerk, C. 2008. Min leerlinge oorweeg deesdae werk as onnie. Beeld Plus Netads24, 30.07.2008.8. Pretoria.

Wenger, E. 1998. Communities of practice: Learning, meaning, and identity. Cambridge University Press: New York.

Woolfolk, A. 2007. Educational psychology. (10th ed.). New York: Pearson. 